\title{
WRONGFUL ARREST: A BRIEF SURVEY OF THE IMPACT OF THE CONSTITUTION IN RECENT CASE LAW*
}

\section{Introduction}

In recent times there has been a proliferation of press reports about ordinary, law-abiding citizens who suffered the indignity and inconvenience of a wrongful (unlawful) arrest at the hands of officers of the South African Police Service or Metro Police Services. According to the most recent of these reports, this increase in the incidence of wrongful arrests have even resulted in deliberations between members of the Law Society of the Northern Provinces and the top management of the SAPS, in which the latter undertook to pay special attention to the training of police officers in order to better the present state of affairs. It is not far-fetched to describe the present situation on the ground in respect of wrongful arrests as epidemic.

In recent interviews with attorneys who have been representing clients in wrongful arrest claims against the Minister of Safety and Security, the present writer was told about certain standard practices regarding arrests: it would seem that it is a favourite practice among certain police officials to arrest suspects on a Friday, or even a Thursday afternoon, in order to prolong the normal 48-hour maximum period of detention before bringing an arrestee before court. Furthermore, metro police spokespersons often announce, at the beginning of some road-safety drive or crack-down on traffic offenders, that certain types of offenders will, without exception, be arrested. The worst recent example recounted to the author of lamentable conduct in this context on the part of a high-ranking police official concerns an order issued on a Friday afternoon in which the officers under his command were ordered to endeavour arresting more persons of a specific ethnic group, seeing that the weekend population of the police cells under his command did not reflect the demographics of his jurisdiction!

\section{Recognition of the rights to liberty and freedom,} security of the person and related rights

Even before the creation of our new Constitution, embodying a Bill of Rights, the courts gave full recognition to the right to liberty, infringement of which is fundamental to a successful delictual claim for wrongful arrest. In Nhlabathi $v$ Adjunk Prokureur-Generaal, Transvaal (1978 3 SA 620 (W) 630A-B) Coetzee $J$ expressed himself as follows:

This note is an adapted version of a lecture entitled "Wrongful arrest: Things ain't what they used to be ... or, has nothing changed?", delivered at the conference of the Society of Law Teachers of Southern Africa in Pietermaritzburg on 13 July 2009. 
"Hierdie grondleggende gedagte dat 'illegal deprivation of liberty is a threat to the very foundation of a society based on law and order' [per Rumpff HR in Wood and Others $v$ Ondangwa Tribal Authority and Another 19752 SA 294 (A) $310 \mathrm{G}$ ] is 'n goue rigsnoer by die vertolking van enige statuut wat betrekking het op die vervolging van landsburgers waar die inperking van òf bewegingsvryheid, ò vryheid in die algemeen ter sprake kom."

The Constitution of the Republic of South Africa, 1996 contains the following relevant sections:

"Section 12 - Freedom and security of the person

(1) Everyone has the right to freedom and security of the person, which includes the right -

(a) not to be deprived of freedom arbitrarily or without just cause;

(b) not to be detained without trial;

(c) to be free from all forms of violence from either public or private sources;

(d) not to be tortured in any way; and

(e) not to be treated or punished in a cruel, inhuman or degrading way.

(2) Everyone has the right to bodily and psychological integrity, which includes the right -
(a) $\ldots$
(b) to security in and control over their body ...
(c) $\ldots$

Section 21 - Freedom of movement

(1) Everyone has the right to freedom of movement.

Section 35 - Arrested, detained and accused persons

(1) Everyone who is arrested for allegedly committing an offence has the right -

(a) $\quad \cdots$

(d) to be brought before a court as soon as reasonably possible, but not later than -

(i) 48 hours after the arrest; or

(ii) the end of the first court day after the expiry of 48 hours, if the 48 hours expire outside ordinary court hours or on a day which is not a court day;

(e) $\ldots$

(f) $\quad \ldots$ ".

\section{$3 \quad$ Wrongful arrest - preliminary observations}

Neethling (Neethling's Law of Personality (2005) 113) gives a sound definition of wrongful arrest:

"Wrongful deprivation of liberty - the genus of which unlawful arrest is a species - as a form of iniuria means that a person is deprived of his physical liberty without legal justification."

Contrast this with the definition of Van der Walt and Midgley (Principles of Delict (2005) 112 (italics supplied)): 
"Wrongful deprivation of liberty consists in the unjustifiable and intentional infliction of a restraint upon the plaintiff's personal freedom."

That the word "intentional" does not bear its normal meaning of animus iniuriandi (viz encompassing the direction of the will, as well as consciousness of wrongfulness) but is applied here in an "attenuated" sense, in which the element of consciousness of wrongfulness is dispensed with, is acknowledged by Van der Walt and Midgley (113 fn 12). This approach has the advantage of dispensing with intention as a substantive element of the delict of unlawful arrest, whilst retaining it in a "formal" sense, which brings this delict under the umbrella of iniuriae as a species of delict. (This rather theoretical aspect will not be pursued further, for purposes of this note.)

The principles pertaining to the English tort of false imprisonment, for which strict liability arises, had a lasting influence on legal developments in South Africa. Lee (An Introduction to Roman-Dutch Law (1953) 325-326) explains that the absence of the animus iniuriandi requirement "is a departure from principle due to the fact that this action, like the action for malicious arrest and the action for malicious prosecution ... is derived from the English Law and governed by English precedents."

In the locus classicus of Birch $v$ Ring (1914 TPD 106 109) De Villiers JP made it clear that the element of intention is lacking from this iniuria:

"Now ... for an action of false imprisonment or illegal arrest to lie it is not necessary that the defendant should act maliciously; it is sufficient that the arrest should be illegal. If he does act maliciously, that will be an element in the estimation of the damages; but the mere false imprisonment or illegal arrest gives a right of action to the person arrested."

From the above it is abundantly clear that the iniuria of wrongful (unlawful, or false) arrest, as a species of wrongful deprivation of liberty, gives rise to strict liability in delict, in spite of its nature as a civil wrong with its roots in the principles underlying the actio iniuriarum. As the normal requirement of animus iniuriandi is not applicable in claims flowing from wrongful arrests, only four delictual elements remain to be proved by a claimant, viz conduct and wrongfulness on the part of the arrestor, as well as a causal nexus between such wrongful conduct and the plaintiff's damage, of which the elements of human conduct and wrongfulness are paramount. The advantage of proceeding against a wrongful arrestor (or his or her employer, in our case law usually the Minister of Safety and Security) by means of a claim for wrongful arrest (as opposed to, or in conjunction with an action for malicious arrest) is that the plaintiff needs merely to prove the act of arrest on the part of the arrestor. If successful, a rebuttable presumption that such arrest has been executed in a wrongful manner arises (Minister of Justice $v$ Hofmeyr 19933 SA 131 (A) 153D-E). The onus then shifts to the defendant to prove that the arrest was in fact lawful. To this end the recognised grounds of justification come into play, of which the most important will certainly be statutory authority on the arrestor's part, as most arrests effected by members of the South African Police Service are authorised, or purported to be authorised, by the Criminal Procedure Act (51 of 1977).

From a practical point of view the placement of this delict in the case law would appear rather strange: virtually all new cases on this topic are 
reported in the South African Criminal Law Reports; commentaries on cases are by and large of those who specialise in criminal procedure (see, eg, the entries under the heading "Criminal Procedure" in the South African Journal of Criminal Justice); and constitutional law principles also permeate this area in recent times. The reason for this phenomenon is that most of the difficulties surrounding this iniuria surface in the domain of the ground of justification just referred to, viz statutory authority - where the main piece of relevant legislation is the Criminal Procedure Act - and that the common-law interests of corpus (see D 47102 ) infringed by an act of wrongful arrest are simultaneously fundamental human rights enshrined in the Bill of Rights (contained in Ch 2 of the Constitution; see the relevant sections referred to under par 2 above). The effect is that the new developments in respect of wrongful arrest cut across the fields of delict, criminal procedure, constitutional law, and even the law of damages and interpretation of statutes. One can truly say that this field lies at the crossroads of the areas just mentioned.

\section{The element of wrongfulness - introductory remarks}

In this note the focus will be exclusively on the delictual element of wrongfulness. Most recent developments in the field of wrongful arrest as a species of civil wrong have indeed occurred in this field.

The well-recognised rules in this regard are as follows: The onus rests on the plaintiff to prove that the act of deprivation of liberty, or freedom of movement - which constitutes an infringement of corpus or bodily integrity as a recognised personality and even fundamental human right - has occurred; and where and when such act of wrongful arrest has occurred (Lombo v African National Congress 20025 SA 668 (SCA) 680G-H; see also Minister of Law and Order $v$ Hurley 19863 SA 568(A) 589; Kabinet van die Tussentydse Regering vir Suidwes-Afrika v Katofa 19871 SA 695 (A) 739; and Minister van Wet en Orde v Matshoba 19901 SA 280 (A) 284). When the plaintiff has discharged this onus, the onus then shifts to the defendant to justify his actions. This is clearly explained in Minister of Justice $v$ Hofmeyr (supra 153D-E):

"The plain and fundamental rule is that every individual's person is inviolable. In actions for damages for wrongful arrest or imprisonment our Courts have adopted the rule that such infractions are prima facie illegal. Once the arrest or imprisonment has been admitted or proved it is for the defendant to allege and prove the existence of grounds of justification of the infraction."

The defendant will normally attempt to discharge this onus by pleading one of the recognised grounds of justification, such as private defence (Robbertse v Minister van Veiligheid en Sekuriteit 19974 SA 168 (T)); necessity (Neethling "Noodtoestand en Noodweer: Regverdigingsgronde by Onregmatige Vryheidsontneming as Iniuria" 1998 THRHR 160); consent (Donono v Minister of Prisons 19734 SA 259 (C)); provocation (cf Bester v Calitz 19823 SA 864 (O) 878-881); or statutory authority.

The latter ground of justification is most frequently resorted to in practice. In respect of arrests effected by peace officers (who include police officers) the Criminal Procedure Act contains detailed provisions. The SAPS Standing 
Orders also provide guidance as to the power of arrest, as well as procedures to be followed in executing an arrest (see the title "Police" in LAWSA (2ed) vol 2(2) par 141-146 for a concise but extremely practical and clear exposition of the applicable principles).

\section{Requirements for a lawful arrest}

Lawful arrest and lawful continued detention after arrest rest on four "pillars" (Bekker, Geldenhuys, Joubert, Swanepoel, Terblanche and Van der Merwe Criminal Procedure Handbook (2007) 99-100):

(i) The arrest (with or without warrant) must have been properly authorised. This entails that a statutory provision must have authorised such arrest.

(ii) The arrestor must exercise physical control over the arrestee. Unless the arrestee submits to custody, the arrestor must limit the arrestee's freedom of movement by actually touching his person or, if circumstances require it, by forcibly confining his person.

(iii) The arrestee must, at the time of arrest or immediately thereafter, be informed of the reason for his arrest.

(iv) The arrestee must be taken to the appropriate authorities as soon as possible. This can either be a police station or, in the case of an arrest with a warrant, the place stipulated in the warrant.

An arrest is usually performed in terms of a valid warrant of arrest. Although various problems pertaining to this kind of arrest have in fact emerged over the last few years, the present discussion will be restricted to arrests without a warrant.

\section{$6 \quad$ Arrest without a warrant}

\section{Section 40(1) of the Criminal Procedure Act}

The power of a peace officer to arrest without a warrant is conferred by section 40(1) of the Criminal Procedure Act, which section has aptly been described as "the gateway to the effecting of arrest by peace officers" (see Cowling "Criminal Procedure" 2008 SACJ 105; on arrest without a warrant, in general, see Bekker et al 102-105; Kriegler and Kruger Hiemstra - SuidAfrikaanse Strafproses (2002) 93-100; and Kruger Hiemstra's Criminal Procedure (2009 loose-leaf) 5-5 to 5-12). Section 40(1) contains no less than 17 paragraphs $(40(1)(a)-(q))$, of which the following four paragraphs are randomly reproduced to afford an example of the scope of this section. Section 40(1)(b), in particular, regularly rears its head in the plea on behalf of the Minister of Safely and Security. The four relevant paragraphs read as follows:

"40(1) A peace officer may without warrant arrest any person -

(a) who commits or attempts to commit any offence in his presence;

(b) whom he reasonably suspects of having committed an offence referred to in Schedule 1 [which Schedule includes a wide range of serious offences, such as treason, public violence, murder, robbery, theft, fraud etc], other than the offence of escaping from lawful custody; 
(c)-(n) $\ldots$

(o) who is reasonably suspected of having failed to pay any fine or part thereof on the date fixed by order of Court under this Act;

(p) $\ldots$

(q) who is reasonably suspected of having committed an act of domestic violence as contemplated in section 1 of the Domestic Violence Act, 1998, which constitutes an offence in respect of which violence is an element."

\section{Survey of selected judgments}

\section{Tsose $v$ Minister of Justice (1951 3 SA 10 (A))}

In this case the plaintiff, who had been squatting on a farm, was arrested by police officers with the exclusive aim of harassing her in order to compel her to leave the farm, and not to bring her before a court of law. The court held that such arrest had been wrongful.

The traditional approach to arrest is reflected in this seminal judgment, in which it was stated that the main purpose of arrest is to bring the arrested person before a court of law. If that purpose is present, any additional motive of the arrestor is irrelevant for purposes of determining the lawfulness of wrongfulness of the arrest in question: "For just as the best motive will not cure an otherwise illegal arrest so the worst motive will not render an otherwise legal arrest illegal" (per Schreiner JA 17G). These words are immediately followed by an explanation that has had a great impact on the practice of effecting arrests ever since $(17 \mathrm{H}$; italics supplied):

"What I have said must not be understood as conveying approval of the use of arrest where there is no urgency and the person to be charged has a fixed and known address; in such cases it is generally desirable that a summons should be used. But there is no rule of law that requires the milder method of bringing a person into court to be used whenever it would be equally effective."

\section{Ex parte Minister of Safety and Security: In re $S v$ Walters (2002 SACR 105 (CC))}

Although this case primarily concerned the constitutionality of statutory provisions which permit force to be applied when carrying out an arrest (viz ss 39(1) and 49(1) of the Criminal Procedure Act), certain parts of the judgment are applicable in a wider context. The first serious indication of the possible incorrectness of the traditional approach to an arrest without warrant in our new constitutional dispensation is to be found in the judgment of Kriegler J (134e), where he expresses himself as follows:

"(a)The purpose of arrest is to bring before court for trial persons suspected of having committed offences.

(b) Arrest is not the only means of achieving this purpose; nor always the best.

(c) Arrest may never be used to punish a suspect." 
(On the effect of this judgment see, generally, Woolman and Brand "Is there a Constitution in this Courtroom? Constitutional Jurisdiction after Afrox and Walters" 2003 SA Public Law 37; see also Currie "Bill of Rights Jurisprudence" 2002 Annual Survey 45-48; and Pantazis and Friedman "Criminal Law" 2002 Annual Survey 816, 840-842.)

The cases which finally "broke the ice" to introduce a new dispensation were handed down in the Pretoria High Court in respect of cases where the defendants relied on section 40(1)(b) of the Criminal Procedure Act which enacts that a peace officer may, without a warrant, arrest any person whom he reasonably suspects of having committed an offence referred to in Schedule 1 (see paragraphs 623 and 624 below).

\section{Ralekwa $v$ Minister of Safety and Security (20041 SACR $131(\mathrm{~T}))$}

The plaintiff had been arrested without warrant in a bank by a police officer on an alleged charge of fraud. However, the charges against him were later withdrawn by the public prosecutor. It was argued, on behalf of the defendant in an action brought by the plaintiff for wrongful arrest, that the police officer's actions could be justified by relying on section $40(1)$ (b) of the Criminal Procedure Act, as fraud is a Schedule 1 offence. However, it was held that as the officer in question had not formed his own opinion as to the possibility of the plaintiff's alleged crime, but had relied solely on the instruction of the branch manager of the bank, it was impossible for him to have "reasonably suspected" that the plaintiff had been guilty of fraud.

In this judgment De Vos J concluded, obiter (see Kriegler "Criminal Procedure" 2004 Annual Survey 685-686), that the approach in Tsose does not meet the standards of a constitutional democracy any more, commenting as follows on that judgment (par [11]):

"There can be no doubt that an examination into the lawfulness of an arrest against the backdrop of a statement that there is no rule of law requiring the milder method of bringing a person into court will be different from an enquiry which starts off on the premise that the right of an individual to personal freedom is a right which should be jealously guarded."

(For unfavourable criticism on certain aspects of this judgment see Cowling "Criminal Procedure" 2004 Annual Survey 685-686.)

\section{Louw $v$ Minister of Safety and Security (2006 2 SACR $178(\mathrm{~T}))$}

In this judgment the plaintiffs were arrested without warrant by a police officer for allegedly stealing a fax machine. In spite of the fact that the plaintiffs had documentary evidence to back up their claim that they had the right to exercise physical control of the machine, the arresting officer ignored that fact and arrested them to "teach them a lesson" for what he regarded as their unacceptable behaviour against the complainant. In essence the court found that the arrest was not covered by section 40(1)(b) of the Criminal 
Procedure Act (see Cowling "Criminal Procedure" 2006 Annual Survey 694695).

In a lengthy obiter judgment Bertelsmann $\mathrm{J}$ followed the lead of De Vos $\mathrm{J}$ in Ralekwa and decided that the time had arrived to state, "as a matter of law" (186b) that, even if a crime which is listed in Schedule 1 of the Criminal Procedure Act has allegedly been committed and even if the arresting police officer believes on reasonable grounds that such a crime has indeed been committed by the arrested person, this in itself does not justify an arrest forthwith (187d-e; italics supplied):

\begin{abstract}
"If there is no reasonable apprehension that the suspect will abscond, or fail to appear in court if a warrant is first obtained for his/her arrest, or a notice of summons to appear in court is obtained, then it is constitutionally untenable to exercise the power to arrest."
\end{abstract}

Bertelsmann $\mathrm{J}$ further opined $(187 \mathrm{~g})$ that this approach does not burden the police unduly.

\title{
625 Charles $v$ Minister of Safety and Security (2007 2 SACR $137(\mathrm{~W}))$
}

In this case, handed down a year later in the Witwatersrand High Court, the plaintiff had been arrested on suspicion of having stolen a firearm. The arresting police officer had relied only on a single witness statement to effect the arrest. However, the charges of theft were later withdrawn. The court came to the conclusion that the arresting officer was protected by section $40(1)(b)$ of the Criminal Procedure Act and accordingly dismissed the delictual claim against the defendant.

In his judgment Goldblatt $\mathrm{J}$ expressed the opinion that Bertelsmann J's judgment in Louw is "clearly wrong" (143j) and that the judgment of Tsose $v$ Minister of Justice still sets out the existing law. To his mind Bertelsmann's approach poses the danger to "open a Pandora's box where the courts would be called upon in cases of this type to have to enquire into what is reasonable in a variety of circumstances and further where peace officers would be called upon to make value judgments every time they effect an arrest in terms of s $40 "$ (143k). This is a very conservative judgment which simply ignores any influence of the Constitution, in effect equating the preand post-constitutional approaches in this field. (For a crisp discussion of the different approaches reflected in Charles and Louw see Cowling 2008 SACJ 106-107.)

\section{Gellman v Minister of Safety and Security (2008 1 SACR $446(W))$}

In this judgment, handed down less than a year after Charles, two judges heard an appeal from the magistrate's court, in which it had been decided that an arrest without warrant had been lawfully effected, simply because the peace officer had seemingly acted in accordance with the provisions of section 40(1)(b) of the Criminal Procedure Act. The plaintiff (appellant) had pointed a firearm at one of his employees who had been threatening to 
assault him. In the process she fled the scene, leaving her handbag behind. She subsequently laid a charge of theft against the plaintiff in respect of the handbag. After having enticed the plaintiff to pay a visit to the charge office in order to make a statement, a police officer arrested him, relying on section $40(1)$ (b) of the Criminal Procedure Act. All charges were subsequently withdrawn.

In allowing the appeal of the plaintiff, the court went further than simply applying section $40(1)(b)$ by deciding that factors such as the risk of the suspect absconding or committing further crimes if not arrested, should also be considered (par [97.5]). Furthermore, the court pointed out that a police officer contemplating an arrest should in final instance follow the instructions contained in the standing orders of the SAPS (par [97.7]), notably Standing Order (G) 341 (issued under Consolidation Notice 15/1999) which emphaticcally mentions that arrest constitutes a drastic infringement of any person's right to freedom and should only be resorted to as a last measure, when other methods of bringing a suspect before a court have failed. Salduker $\mathrm{J}$ and Levenberg AJ in so many words endorsed the judgment of Bertelsmann $J$ in the Louw case.

\section{Minister of Safety and Security $v$ Van Niekerk (2008 1 SACR 56 (CC))}

At this stage it would seem that there are two strands of thought: that represented by Ralekwa, Louw and Gellman on the one, and Charles, on the other hand. A chance to settle the matter once and for all arose in the Constitutional Court in the judgment of Minister of Safety and Security $v$ Van Niekerk, but the court avoided providing guidance in this matter, when Sachs $\mathrm{J}$ simply declared that "the constitutionality of an arrest will almost invariably be heavily dependent on its factual circumstances" (61e-f), which simply takes us nowhere. Cowling drew attention to this (2008 SACJ 321) when he expressed the opinion that the dichotomy needs to be resolved and "it is to be hoped that when this happens such court does not attempt to avoid the issue as did the Constitutional Court in Van Niekerk".

This academic commentator also pointed out that the Constitutional Court, "[i]n a measure of deference to law and order authorities" (Cowling 2008 SACJ 321), remarked that "those involved in the day-to-day exercise and supervision of the power to make arrests are usually best positioned to establish appropriate operational parameters concerning the discretion to arrest" $(61 \mathrm{~g}-62 \mathrm{a})$. The court expressed the opinion that the best way to go about this was probably to rely on internal regulation of the matter by the SAPS, for example by applying its standing orders (in particular Standing Order (G) 341 issued under Consolidation Notice 15/1999 dealing with arrest and the treatment of arrestees, stating, inter alia, that members of the SAPS exercising the power of arrest "should therefore regard it as a last resort"). That this last remark of the court does not imply that the Constitutional Court has "abandoned" its discretion in this sphere to the discretion of members of the SAPS, applying their internal standing orders, is borne out in the case of Le Roux v Minister of Safety and Security (2009 4 SA 491 (N): see the discussion of this judgment under par 6210 in fin below). 


\section{Ramphal $v$ Minister of Safety and Security (2009 1 SACR 211)}

In this very recent judgment Plasket $\mathrm{J}$ allowed the appeal of someone who had unsuccessfully claimed damages from the Minister of Safety and Security in the magistrate's court. The facts were that the plaintiff (appellant) had been arrested by the arresting officer on the instructions of a public prosecutor, without having applied his mind to the question whether he had had any reasonable grounds for effecting the arrest.

In rejecting the judgment of the court a quo, the court gave us a very good formula for approaching the type of problem at hand (215a):

"The magistrate erred. Our constitutional order is founded on the rule of law.

That means, at least, that every exercise of public power, in order to be valid,

be authorised by law"

It is suggested that this is a most simple, but highly effective manner to dispense with difficulties arising in the sphere of evaluating the lawfulness or wrongfulness of an arrest by a peace officer: It is clear that the measures contained in section 40(1) of the Criminal Procedure Act constitute the basis for the exercise of the power of arrest - a public power. It was not necessary for the court to decide, in this specific case, whether the arrestor needed to apply his discretion beyond the limits of section $40(1)(b)$, as it was held that his actions fell short of the requirements of that paragraph of the Act. However, it is suggested that this judgment provides a fitting guideline for the correct method of determining the lawfulness or wrongfulness of an arrest in the idiom of a constitutional state. In this way it can be interpreted as supporting the judgments of Ralekwa, Louw and Gellman (see further Palmer and Cowling "Criminal Procedure" 2009 SACJ 99).

\section{Brown $v$ Director of Public Prosecutions (2009 1 SACR 218)}

This is the penultimate reported judgment on wrongful arrest at this point in time. Although it deals with an arrest effected in terms of a valid warrant of arrest, Fourie $\mathrm{J}$ made some comments of a general nature which is pertinent in the field of arrests without warrant.

First, he emphasised (221d) that the point of departure in deciding cases of this nature should be the Constitution, in particular section 12(1), dealing with freedom and security of the person.

Secondly, he again reminded us that the general object of an arrest is to bring the arrested person before a court to be charged, tried and then either convicted or acquitted. "If the person effecting the arrest has an ulterior motive for the arrest, for example, to intimidate or to punish the arrested person, the arrest will be unlawful" (221g-h). It is suggested that this flies in the face of Tsose's judgment, reflecting the traditional approach to an arrest without warrant. 
Thirdly, Fourie $\mathrm{J}$ appeared to prefer the judgment of Bertelsmann $\mathrm{J}$ in Louw to that of Goldblatt $\mathrm{J}$ in Charles, if one considers the following dicta: "In my opinion, there is much to be said for this view [viz of Bertelsmann J], provided, of course, that each case has to be dealt with on its own merits" (222a). After merely referring to the fact that Goldblatt J's approach in Charles differs from that of Bertelsmann $\mathrm{J}$, Fourie $\mathrm{J}$ concluded on this aspect: "It should, however, be noted that Goldblatt $\mathrm{J}$ added the following qualification at 144d-e: 'Obviously the position will be different if the action of the policeman is mala fide or an abuse of the right of arrest given to him ..." (222c-d). It needs no further explanation to conclude that these words also deviate from the rule stated in the Tsose judgment, which reflects the traditional approach.

Fourthly, the judge briefly set out the effect of the Gellman judgment, without in any way expressing reservations as to its correctness.

Fifthly, he reiterated his approval of the "constitutional approach" to the power of arrest, by referring to the method adopted in the Louw case (227bc, my emphasis):

"I agree with the view expressed by Bertelsmann $\mathrm{J}$ in Louw and Another $v$ Minister of Safety and Security and Others (supra) at 186c, that any arrest being as drastic an invasion of personal liberty as it is, must still be justifiable according to our Bill of Rights. Put differently, the conduct of the person effecting an arrest should not constitute an abuse of the right given to such person to effect the arrest." 101.)

(For a favourable appraisal of this judgment see Palmer and Cowling 99-

\section{Le Roux $v$ Minister of Safety and Security (2009 4 SA $491(\mathrm{~N}))$}

In this, the latest reported case dealing with wrongful arrest at the time of writing this note, the plaintiff (appellant) was arrested and detained by a police officer after she had initially, in the course of an investigation of a case of reckless or negligent driving against him, decided not to detain him. She later changed her mind and decided to detain him in terms of section 40(1) of the Criminal Procedure Act (seeing that the offence with which he had been charged fell within the ambit of Schedule 1 of that act), her main reason for this change of mind being to demonstrate to her black colleagues that she, as a white person, did not have any racial prejudice in favour of the plaintiff, who was also a white person. The court held that, as the plaintiff posed no danger to society, was willing to attend court proceedings to stand trial, being in fact able and keen to disprove the allegations against him and posed no threat to others, nor had been the object of threats of harm from any other person or persons, his arrest had been wrongful. The judgment of the magistrate's court in favour of the defendant (respondent) was thus reversed.

It is noteworthy that Madondo $\mathrm{J}$ referred to the approach in Tsose as the "pre-constitutional approach by our courts and our law enforcement authorities" (496I), quoting the relevant parts of that judgment in full (496J- 
497B). After a detailed analysis of the requirements of compliance with section 40(1) of the Criminal Procedure Act (497C-499F) the court expressed itself as follows $(499 \mathrm{G}-\mathrm{H})$ :

"[29] Prior to the advent of the Constitution our courts were duty-bound to give effect to the legislation even when it was destructive of liberty. Section 39(2) of the Constitution now permits our courts to ensure that all legislation is interpreted in such a way as to ensure that liberty is protected, except in the circumstances in which the Constitution sanctions its deprivation.

[30] The court must not only be content with the finding that the arrest of a suspect fell squarely within the parameters of $s 40(1)(b)$ of the Act. It must also look beyond the provisions of the section to the principles and provisions of the Constitution relating to the right to liberty and freedom in order to determine whether the arrest was justified."

After further referring to the conflicting judgments in Louw and Gellman on the one, and Charles on the other hand $(499 \mathrm{~J}-500 \mathrm{H})$ and noting the unwillingness of the Constitutional Court in Van Niekerk to "articulate a blanket all-purpose test for constitutionally acceptable arrests" (501E), Madondo $\mathrm{J}$ reiterated the view that compliance with section 40(1)(b) of the Criminal Procedure Act by an arresting officer is not sufficient to justify an arrest without a warrant, but that "[t]here must be a just cause before the arresting officer derogates from the protection afforded by $s 12$ of the Constitution" (502E). The absence of a "just cause" would indeed make an arrest arbitrary and for that reason point to wrongful conduct on the arresting officer's part (see the references to the English case of Crewe $v$ Social Security Commissioner [1982] 2 All ER 745 (CA) 749 and the Canadian case of Collins v Brantford Police Services Board [2001] 87 CRR (2d) 4 in respect of the "just cause" requirement). The judge then came to the conclusion that the arresting officer's change of mind in deciding to arrest the plaintiff, motivated by her desire to dispel perceptions of racial prejudice on her part, had not constituted a just cause as just explained and that the judgment in the court a quo which favoured the defendant "did not demonstrate that it used constitutional principles or provisions ... as its yardstick in determining the lawfulness of the arrest ..." (503C).

Msimang $\mathrm{J}$, in a separate judgment, concurred with Madondo J's judgment and rendered his own appraisal of the case law discussed by the latter. Noteworthy is his slightly stronger rejection of the pre-constitutional position expounded in the Tsose judgment and reflected in Charles (509CD):

"[70] The Charles pronouncement on the issue smacks of the system of parliamentary sovereignty of the pre-constitutional era. We have fortunately outlived that era and now live under a new Constitutional dispensation wherein 'every exercise of power is expected to be justified; in which the leadership given by government rests on the cogency of the case offered in defence of its decisions, not the fear imposed by the force at its command' [ref to Mureinik "A Bridge to Where - Introducing the Interim Bill of Rights" 1994 SA Journal of Human Rights 31 32].

[71] The views expressed in Louw (supra) are in sync with the Constitution and are therefore to be preferred."

One last observation in respect of the judgment of Msimang $\mathrm{J}$ concerns his reference to the relevance of Standing Order (G) 341 (issued under 
Consolidation Notice 15/1999), dealing with arrest and the treatment of arrested persons (509F). Criticising the interpretation of that standing order by the court a quo as being unintelligible, he added that it merely contained departmental guidelines to guide police officers in the exercise of their discretion under section 40 of the Criminal Procedure Act and that "[t]hose guidelines can certainly not stand in the way of a constitutional imperative" (510C).

\section{$7 \quad$ Conclusion}

In view of the dicta and findings in eight out of the nine judgments reported since 2002 that are discussed above - Charles being the exception - one may surely be permitted to draw the conclusion that a new era has finally dawned in the sphere of judging the lawfulness or wrongfulness of arrests effected by peace officers without a warrant, in terms of section 40(1) of the Criminal Procedure Act. The question immediately arises: What is the present position concerning arrests in terms of a valid warrant of arrest? Although this question was not touched upon in the course of this note, it is suggested that constitutional imperatives may have an effect in that sphere as well. The launching of an investigation into that matter would seem to be a worth-while challenge, in particular to those with an interest in the law of criminal procedure and constitutional law.

It is worthwhile quoting in extenso from an article by Plaskett ("Controlling the Discretion to Arrest without Warrant through the Constitution" 1998 SACJ 173 194) in order to demonstrate the almost prophetic foresight contained in it in respect of the reforms that started taking shape in the law pertaining to liability for wrongful arrests since 2002; and to recognise its influence in this reform process. Approving references to it can be found in the cases of Louw (186h-187c), Gellman (464d-j) and the judgment in Ramphal which was written by Plaskett J:

"The fundamental rights to freedom and to justifiable administrative action have, by rendering the offensive part of Tsose's case redundant, placed the discretion to arrest on the same footing as the exercise of any other discretionary power. In the context of the high premium placed by the Constitution on the rights to human dignity and freedom, that is important: the courts are now provided with the means to protect these rights effectively (having failed to develop meaningful safeguards themselves), thus ensuring that the drastic power of arrest without warrant is controlled by the full spectrum of the principles of legality, procedural propriety and rationality. This is not as radical a departure as some may imagine; after all, the idea of justifiability, principally articulated through a duty to consider less drastic alternatives, is part of the police standing orders, which bind every police official in the exercise of his/her duties and functions. Despite this, there may be those who perhaps, in claiming to champion the war against crime, appear to believe that the police should be freed of legal constraints. No one would suggest that the level of crime in our country is not an extremely serious problem. It is obvious that decisive steps have to be taken to address the problem. On the legal level the answer lies in convicting and sentencing criminals in fair trials. For the police that means improving their capacity to detect crime and investigate offences. It goes without saying that this should be done within the framework of the Constitution ... The power to arrest plays a minor role in the endeavour to combat crime: it is merely a means, and only one of a number of means, to initiate the process of prosecution. An increase in the number of arrests may not be an indication that the war against crime is 
being won. It may instead be an indication that our constitutional rights and freedoms are being devalued."

Finally, one hardly needs to point out that law enforcement authorities disregarding the impact of our Constitution on the law pertaining to arrests will certainly be running into difficulties when confronted by disgruntled arrestees. A drastic change of attitude on their part will be necessary to stem the steady flow of judgments delivered in favour of those who have been arrested without due consideration having been given to constitutional imperatives.

Johan Scott University of Pretoria 